open access to endoscopy. This could lead to more satisfied patients, more efficient use of limited endoscopy resources, and happier general practitioners.

C BROWN Registrar

W D W REES Consultant

Department of Gastroenterology,

University of Manchester School of Medicine,

Hope Hospital,

Salford M6 8HD

I De Dombal FT. Analysis of foregut symptoms. In: Baron JH, Moody FG, eds. Butterworth international medical review. Gastroenterology. I. Foregut. London: Butterworth, 1981:49-66.

2 Barbara L, Camilleri M, Corinaldesi R, et al. Definition and investigation of dyspepsia. Consensus of an international ad hoc working party. Dig Dis Sci 1989;34:1272-6.

Jones $\mathrm{R}$, Lydeard S. Prevalence of symptoms of dyspepsia in the community. Br Med $\mathcal{J}$ 1989;298:30-2.

4 Moynihan BGA. On duodenal ulcer: with notes of 52 operations. Lancet 1905;i:340-6.

5 Davenport PM, Morgan AG, Darborough A, et al. Can preliminary screening of dyspeptic patients allow more effective use of investigational techniques? BrMed f 1985;290:217-20.

6 Williams B, Luckas M, Ellingham JHM, et al. Do young patients with dyspepsia need investigation? Lancet 1988;ii:1349-51.

7 Talley NJ, McNeil D, Piper DW. Discriminant value of dyspeptic symptoms: a study of the clinical presentation of 221 patients with dyspepsia of unknown cause, peptic ulceration and cholelithiasis. Gut 1987;28:40-6.

8 Crean GP, Spiegelhalter DJ. Symptoms of peptic ulcer. In: Brooks FP, Cohen S, Soloway RD, eds Contemporary issues in gastroenterology, peptic ulcer disease. Edinburgh: Churchill Livingstone, 1985:1-15.

9 Chesner IM. Whom should we endoscope? Hospital Update 1989;15:47-54

10 Health and Public Policy Committee, American College of Physicians. Endoscopy in the evaluation of dyspepsia. Ann Intern Med 1985;102:266-9.

11 Schiller LR, Fordtran JS. Ulcer complications during short term therapy of duodenal ulcer with active agents and placebo. Gastroenterology 1986;90:478-81.

12 Armstrong CP, Blower AL. Non-steroidal anti-inflammatory drugs and life threatening complications of peptic ulceration. Gut 1987;28:527-32.

\section{Lead poisoning: an age old problem}

\section{Many more workers may be at risk than those currently monitored}

Lead is ubiquitous in the environment as a result of its natural occurrence and industrial use. ${ }^{1} \mathrm{~A}$ healthy adult will have an average daily intake of about $100 \mu \mathrm{g},{ }^{2}$ most of it from food and water, though inhalation of lead from polluted environments may also be important. About $10-30 \%$ of inhaled lead and $10-15 \%$ of ingested lead is absorbed, ${ }^{3}$ and the balance of absorption and excretion normally maintains blood lead concentrations below $1 \cdot 0 \mu \mathrm{mol} / \mathrm{l}$. People occupationally exposed to lead may, however, rapidly accumulate toxic concentrations. In Britain there are about 25000 registered lead workers under medical surveillance, but two recent outbreaks of lead poisoning - one in Britain ${ }^{4}$ and the other in the United States ${ }^{5}$ - suggest that many more may be at risk. In both cases those affected were demolition workers who used oxyacetylene torches to cut through metal covered in lead based paints, and the outbreaks came to light only when workers sought medical advice because of their symptoms.

Though the toxic effects of inorganic lead have been known since ancient times ${ }^{6}$ - the classic clinical features were reported by physicians in the eighteenth and nineteenth centuries, most notably by Tanquerel des Planches in his treatise of
$1839^{-}$- modern clinical experience in developed countries is limited because industrial legislation has restricted occupational exposure. In addition, lead poisoning is often not recognised because of its non-specific symptoms. The typical abdominal pain may not be colicky, and features such as fatigue, arthralgia, myalgia, headache, irritability, and depression are common. ${ }^{8}$ Furthermore, up to a third of patients volunteer no complaints at examination. ${ }^{910}$ Thus a careful history of the patient's work and home environment may save the patient and clinician a series of unsuccessful diagnostic tests. In the outbreak among British demolition workers reported by Pagliuca et $a l^{+}$classic basophilic stippling seen on the peripheral blood film ${ }^{11}$ raised the suspicion of lead poisoning, which was easily confirmed by checking blood lead and erythrocyte zinc protoporphyrin concentrations. Treatment with chelating agents such as sodium calciumedetate, dimercaprol, penicillamine, and the relatively new water soluble agents dimercaptosuccinic acid and dimercaptopropane sulphonate ${ }^{12}$ is gratifyingly effective, but prevention is still better than cure.

In Britain exposure to lead at work is strictly controlled by the Health and Safety Executive, ${ }^{13}$ and those working in processes that create lead dust (powder mixing, sanding, grinding, and scraping) or fumes (burning, refining, pouring, smelting) are kept under medical surveillance. Few cases of lead poisoning are notified outside the surveillance scheme. ${ }^{1}$ In the United States an estimated 827650 workers have potential occupational exposure to lead, ${ }^{15}$ and extrapolating these figures to Britain suggests that many more British workers may be at risk than are currently monitored. With the demolition and reconstruction industries now thriving in many inner city revitalisation programmes we may see an increase in the number of cases of occupational lead poisoning. World wide it remains the most common occupational poisoning and we should remain ever vigilant.

ANTONIO PAGLIUCA Sir John Dacie Research Fellow

GHULAM J MUFTI Senior Lecturer

Department of Haematological Medicine,

King's College School of Medicine and Dentistry,

London SE5 8RX

1 Waldron HA. Diseases associated with chemical agents: metals. In: Raffle PAB, Lee WR, McCallum RI, Murray R, eds. Hunter's diseases of occupations. 7th ed. London: Hodder and Stoughton, 1987:240-50.

2 Elwood PC. Changes in blood lead concentrations in women in Wales 1972-1982. Br Med $\mathcal{J}$ 1983;286:1553-5.

3 Barry PSI. Lead: occupational and environmental exposure. In: Gardner WA, ed. Curren approaches to occupational medicine. Bristol: John Wright, 1979.

4 Pagliuca A, Mufti GJ, Baldwin D, Lestas AN, Wallis RM, Bellingham AJ. Lead poisoning: the clinical, biochemical and haematological aspects of a recent outbreak. $\mathcal{F}$ Clin Pathol (in press).

Himmelstein J, Wolfson M, Pransky G, Morse D, Ross A, Gill J. Lead poisoning in bridge Himmelstein J, Wolfson M, Pransky G, Morse D, Ross A, Gill
demolition workers - Massachusetts. MMWR 1989;38:687-93.

demolition workers - Massachusetts. MMWR 1989;38.687-93.

6 Waldron HA. Lead poisoning in the ancient world. Med Hist 1973;17:391-9.

7 Tanquerel des Planches LJCM. Trates des maladies de plomb ou saturnines. Paris: Ferra, 1839. Cullen MR, Robins JM, Eskenazi B. Adult inorganic lead intoxication: presen
and a review of recent advances in the literature. Medicine 1983;62:221-47.

9 Keogh JP. Recognizing lead poisoning in adults. Arch Intern Med 1984;144:1944-5.

10 Dunea G. Neuromeanderings. Br Med $\mathcal{J}$ 1987;295:1469-70.

11 Albahary C. Lead and hemopoiesis. Am J Med 1972;52:367-78

2 Aposhian HV. DMSA and DMPS - water soluble antidotes for heavy metal poisoning. Annu Rev Pharmacol Toxicol 1983;23193-215.

3 Health and Safety Executive. Control of lead at work. Approved code of practice. London: HMSO, 1985.

14 Thomas PG, Jones RD. Control of lead at work - men under surveillance 1982-1986. Employmen Gazette. December 1988:664-70.

15 Anonymous. Editorial note. $M M W R$ 1989;38:693-4. 